\title{
Determination of Trace Amounts of Copper in River and Sea Water Samples by Flame Atomic Absorption Spectrometry (FAAS) after Cloud-point Preconcentration
}

\author{
Nasser Goudarzi* \\ Faculty of Chemistry, Shahrood University of Technology, P.O. Box 316, Shahrood, Iran
}

\begin{abstract}
Este trabalho propõe um novo método de pré-concentração baseado em ponto nuvem para a determinação de cobre. O reagente 1,5-difenil-benzoína (Cupron) foi usado como complexante e Triton X-114 foi adicionado como surfactante. Após a separação das fases e diluição da fase rica em surfactante com metanol em meio acidificado foi feita a determinação do cobre por espectrometria de absorção atômica com chama (FAAS). O fator de enriquecimento do cobre, após a otimização das condições de complexação e otimização, foi igual a 88 . O procedimento proposto possibilitou a determinação de cobre com limite de detecção igual a $0,04 \mu \mathrm{g} \mathrm{L}^{-1}$. O procedimento foi aplicado com sucesso na determinação de cobre em amostras de água de rio e de mar. O desvio padrão relativo foi de 1,9 \% para o $\mathrm{Cu}$. Também foram investigados efeitos de interferência de alguns ânions e cátions.
\end{abstract}

A new preconcentration method was proposed using the cloud point approach for copper determination. The reagent 1,5-diphenyl-benzoin (Cupron) was used as a complexing agent and Triton X-114 was added as a surfactant. After phase separation, dilution of the surfactantrich phase was carried out using acidified methanol and the copper content was subsequently measured by flame atomic absorption spectrometry. After optimization of the complexation and extraction conditions, the enrichment factor for $\mathrm{Cu}$ was found to be 88 . The proposed procedure allowed determination of the copper content with the detection limit of $0.04 \mu \mathrm{g} \mathrm{L}^{-1}$. The method was successfully applied to copper determination in river and sea water samples. The relative standard deviation for the method was found to be $1.9 \%$ for $\mathrm{Cu}$. The interference effects of some anions and cations were also investigated.

Keywords: cupron, cloud-point extraction (CPE), copper, FAAS

\section{Introduction}

Trace elements play important roles in biological processes, the compounds of which serve both as essential compounds and as toxins. Copper is both vital and toxic for many biological systems. Thus, the determination of trace amounts of copper is becoming increasingly important because of the growing interest in environmental pollution. Much interest and effort have been devoted to the studies of copper determination in water and biological matrices because it is a good tool for environmental and toxicological monitoring. Removal of copper from aqueous mediums such as effluents is also of great interest for environmental and human health purposes. ${ }^{1}$ Copper is an essential element for enzymes but above a healthy limit it accumulates in liver, causing dizziness, vomiting,

*e-mail: goudarzi10@yahoo.com; goudarzi@shahroodut.ac.ir diarrhea, transpiration and, depending on its concentration, death from bleeding. ${ }^{2}$

Generally, determination of an extremely low concentration of this element is associated with separation and preconcentration steps due to insufficient sensitivity or matrix interference. Moreover, aqueous micellar solutions can replace the more dangerous and toxic organic solvents allowing us to perform the analysis under mild conditions. ${ }^{3,4}$ Quantification of low concentrations of metals requires either very sensitive instrumental techniques or preconcentration to achieve detection limits within the range of the available equipment. ${ }^{5}$ This procedure is attractive when flame atomic absorption spectrometry (FAAS), a relatively simple and available technique in many laboratories, is used. Classical liquid-liquid extraction and separation methods are usually time consuming and labor extensive and require relatively large volumes of high-purity solvents. Of additional concern is the disposal of the solvent following use, which creates a severe environmental 
problem. Cloud-point extraction (CPE) is an attractive technique that reduces the solvent consumption and it also reduces disposal costs and extraction time. ${ }^{6-14}$ Cloud-point extraction is probably the most versatile and simplest method for the preconcentration and extraction of hydrophobic species from water. The technique is based upon a property of most non-ionic surfactants in aqueous solutions: to form micelles and become turbid when heated to a temperature known as the cloud-point temperature (CPT). Above this temperature, the micellar solution separates in a surfactantrich phase, in which the surfactant concentration is close to the critical micellar concentration (CMC). ${ }^{15}$ This phenomenon, which is especially observable with polyoxyethylene surfactants, could be attributed to the ethyl oxide segments in the micelle, which repel each other at low temperatures and attract each other at high temperatures. $^{16}$

The cloud point phenomenon is reversible and when the temperature falls below the CPT, a single phase appears again. Compared with the recent developments in preconcentration and determination of $\mathrm{Cu}$, the proposed method is simple and sensitive. ${ }^{17,18}$ The phase separation phenomenon has also been used for the extraction and preconcentration of metal ions after the formation of sparingly water-soluble complexes. ${ }^{19,20}$ $\mathrm{CPE}$ as a preconcentration step in conjunction with spectrophotometry, FIA-spectrofluorimetry, FAAS, ETAAS, ICP-AES, and HPLC for the determination of various metal ions have been widely studied. ${ }^{21-28} \mathrm{CPE}$ combination with FAAS for determination of manganese and iron has also been reported. ${ }^{29-34}$ In the present work we report the results obtained from studying the CPE to determine the $\mathrm{Cu}$ content of sea and river waters by using Cupron as a complexing agent and Triton X-114 as a surfactant. FAAS was used for the detection.

\section{Experimental}

\section{Apparatus}

A Perkin-Elmer model 232-A atomic absorption spectrometer equipped with a copper hollow-cathode lamp as a radiation source was used throughout the measurement made at $324.7 \mathrm{~nm}$. The acetylene flow rate and the burner height were adjusted in order to obtain the maximum absorbance signal, while aspirating the analyte solution in methanol. A thermostated bath maintained at the desired temperature was used for cloud point preconcentration experiments and phase separation was assisted using a centrifuge.
Materials

All reagents used were of analytical-reagent grade. Stock solutions of $\mathrm{Cu}\left(1000 \mathrm{mg} \mathrm{L}^{-1}\right)$ and those used for the interference study $\left(100 \mathrm{mg} \mathrm{L}^{-1}\right)$ were prepared by dissolving appropriate amounts of their respective salts in doubly distilled water. The non-ionic surfactant Triton X-114 (Fluka Chemie AG, Switzerland) was used without further purification. 1,5-diphenyl-benzoin (Cupron) (Fluka Chemie AG, Switzerland) was dissolved in 99.8 $\%$ methanol. A stock buffer solution $\left(1 \mathrm{~mol} \mathrm{~L}^{-1}\right)$ was prepared by dissolving appropriate amounts of acetic acid and sodium acetate in water. The pipettes and vessels used for the trace analysis were kept in sulfochromic acid mixture for at least 1 hour and subsequently washed four times in succession with water. The copper stock solution was prepared by dissolving $1.0000 \mathrm{~g}$ copper powder in concentrated nitric acid and then diluted to $1.0 \mathrm{~L}$ in a volumetric flask. The other $\mathrm{Cu}$ solutions were prepared by dilution of appropriate volumes of the stock solution.

\section{Procedures}

For CPE, aliquots of $60 \mathrm{~mL}$ solutions containing the analyte, $0.1 \%(\mathrm{~m} / \mathrm{v})$ Triton X-114 and $1 \times 10^{-4} \mathrm{~mol} \mathrm{~L}^{-1}$ Cupron buffered at a suitable $\mathrm{pH}$ were placed for $10 \mathrm{~min}$ in a thermostatic bath maintained at $50{ }^{\circ} \mathrm{C}$. Phase separation was achieved by centrifugation at $3500 \mathrm{rpm}$ for $10 \mathrm{~min}$. The phases were cooled in an ice bath to increase the viscosity of the surfactant-rich phase. The bulk aqueous phase was easily decanted. To reduce its viscosity, the remaining micellar phase $(200 \mu \mathrm{L})$ was dissolved in $800 \mu \mathrm{L}$ of methanolic solution of $0.1 \mathrm{~mol}$ $\mathrm{L}^{-1} \mathrm{HNO}_{3}$. The final solution (approximately $1.0 \mathrm{~mL}$ ) was introduced into air acethylene flame by conventional aspiration.

\section{Results and Discussion}

\section{pH effect}

The $\mathrm{pH}$ was the first parameter evaluated in the determination of the copper content. For this study, acetate, borate and ammoniacal buffers were used at different $\mathrm{pH}$ values. The effect of the sample $\mathrm{pH}$ on the copper response was investigated within the range 2.09.0. As can be seen in Figure 1, the best $\mathrm{pH}$ range for $\mathrm{Cu}$ (II) maximum extraction efficiency was 5.8-6.2. Therefore, the sample $\mathrm{pH}$ was maintained at 6.0 using acetate buffer in this study. 


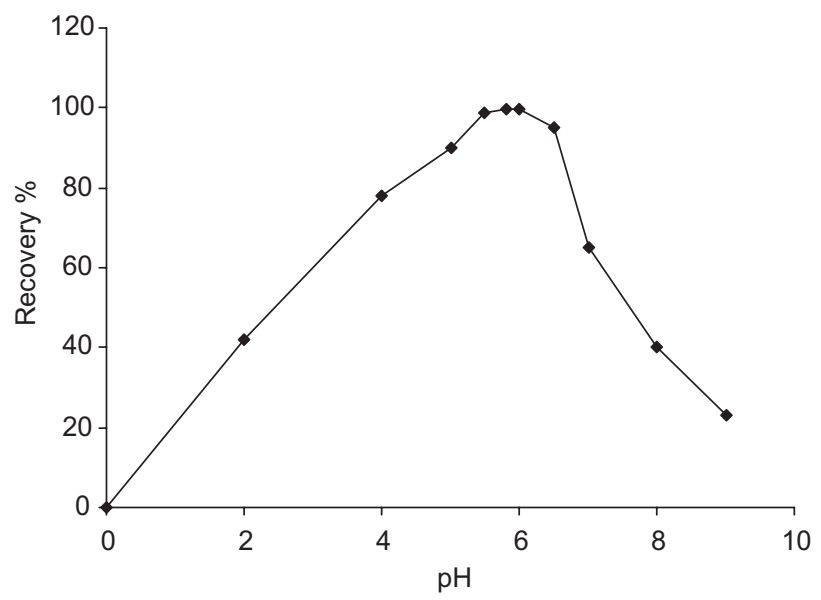

Figure 1. Effect of $\mathrm{pH}$ on the CPE-preconcentration performance: $\mathrm{Cu}$ $\left(20 \mu \mathrm{g} \mathrm{L}^{-1}\right)$; Triton X-114 $0.05 \%$ (v/v); Cupron $1 \times 10^{-4} \mathrm{~mol} \mathrm{~L}^{-1}$.

\section{Triton X-114 concentration effect}

The effect of surfactant concentration was studied within the Triton $\mathrm{X}-114$ concentration range from $5 \times$ $10^{-3}$ to $2 \times 10^{-1} \%(\mathrm{v} / \mathrm{v})$. The surfactant Triton X-114 was chosen due its commercial availability and low cloud point temperature and high density of the surfactant rich phase, which facilitates phase separation by centrifugation. Figure 2 shows the effect of the surfactant concentration on the analytical signal. The maximum signal was observed when Triton X-114 concentration was $0.05 \%(\mathrm{v} / \mathrm{v})$. At concentrations higher than $0.05 \%$ $(\mathrm{v} / \mathrm{v})$, the analytical signal decreased, probably due to the increase in the surfactant volume, which deteriorates the FAAS signal. At concentrations below this value, the extraction efficiency of complexes was low because there are few surfactant molecules to entrap the $\mathrm{Cu}$ Cupron complex quantitatively. Accordingly, a concentration of $0.05 \%$ Triton X-114 (v/v) was chosen for use in the subsequent experiments.

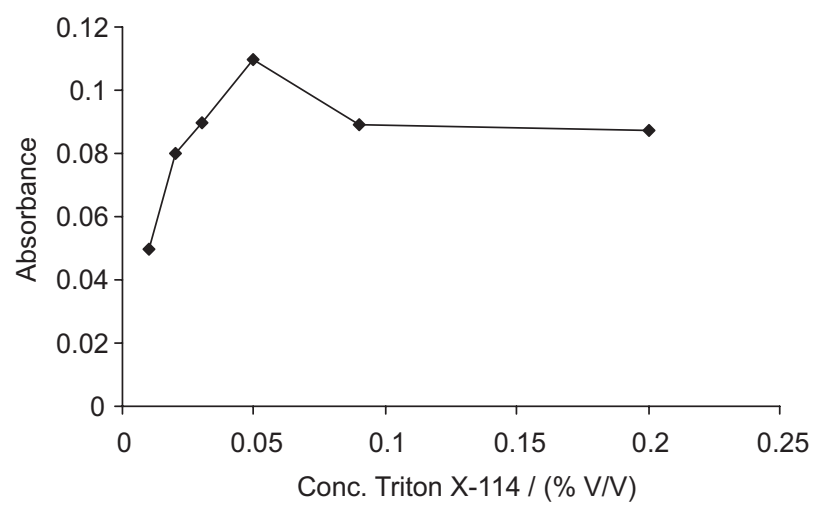

Figure 2. Effect of the Triton X-114 concentration on the CPE preconcentration performance: $\mathrm{Cu}\left(20 \mu \mathrm{g} \mathrm{L}^{-1}\right) ; \mathrm{pH}, 6.0$; Cupron, $1 \times$ $10^{-4} \mathrm{~mol} \mathrm{~L}^{-1}$.

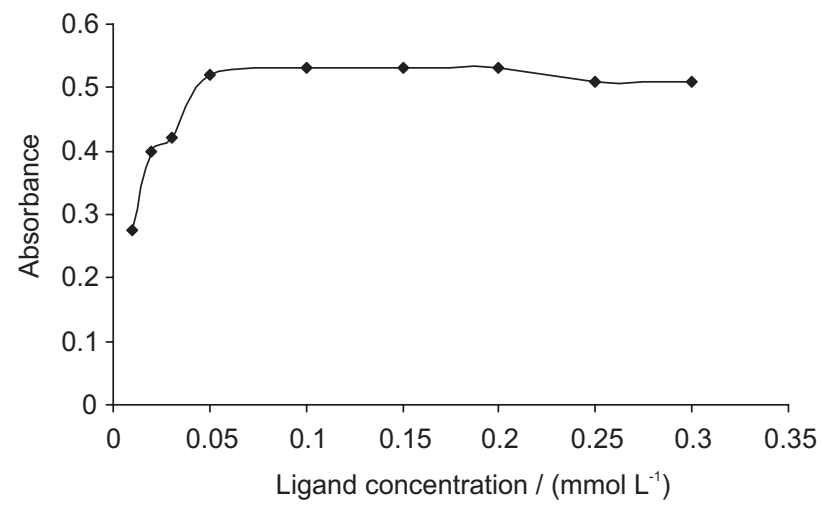

Figure 3. Effect of the Cupron concentration on the CPE- preconcentration performance: $\mathrm{Cu}\left(20 \mu \mathrm{g} \mathrm{L}^{-1}\right) ; \mathrm{pH}, 6.0$; Triton X-114 0.05\% (v/v).

\section{Effect of Cupron concentration}

In this part the effect of different concentrations of the chelating agent Cupron on the analytical response was studied. Under the optimum $\mathrm{pH}$, the effect of the cupron concentration as a chelating agent was studied on the analytical signal and the results were shown in Figure 3. It is clear from Figure 3 that the signal increases up to the concentration of $0.8 \times 10^{-3} \mathrm{~mol} \mathrm{~L}^{-1}$, reaching a plateau, considered as complete extraction. A concentration of $1 \times 10^{-4} \mathrm{~mol} \mathrm{~L}^{-1}$ was chosen as the optimum concentration for the subsequent experiments.

\section{Equilibration temperature and time effect}

The equilibration temperature above the cloud point and equilibration time was thoroughly optimized. It was desirable to employ the shortest equilibration time and the lowest possible equilibration temperature, a compromise between completion of extraction and efficient separation of the phases. Figure 4 clearly shows that a temperature of $50^{\circ} \mathrm{C}$ is adequate for the experiment. At lower temperatures separation of the two phases is not complete. The dependence of extraction efficiency on equilibration time was studied for a time interval of 5-25 min. An equilibration time of $10 \mathrm{~min}$ was chosen to be optimal to achieve a quantitative extraction.

\section{Calibration, precision and detection limits}

Calibration graphs were obtained by preconcentration of $60 \mathrm{ml}$ of the sample in the presence of $0.05 \%$ Triton X$114(\mathrm{v} / \mathrm{v})$ under optimum experimental conditions. Table 1 gives the parameters for the calibration graphs, the relative standard deviations obtained for ten samples subjected to the complete procedure and the detection limits. The preconcentration factor calculated as the ratio 


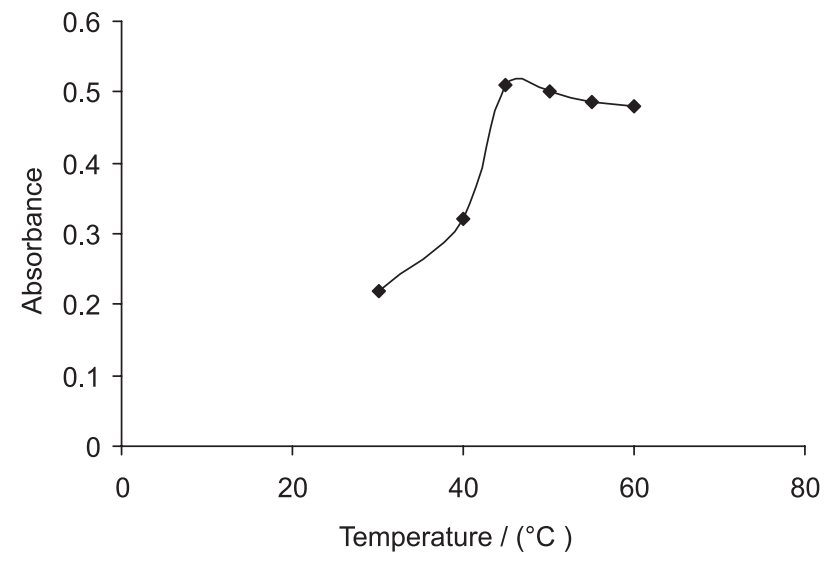

Figure 4. Effect of temperature on the CPE-preconcentration performance: $\mathrm{Cu}$

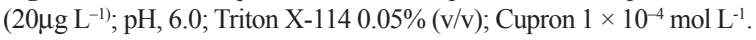

of the concentration of the analyte after preconcentration to that before preconcentration which gives the same absorbance peak area was 88 for $\mathrm{Cu}$. However, the preconcentration factors reported by other studies were usually obtained by using larger sample volumes. Furthermore, the need-to-handle volume of the final methanolic solution was estimated to be sufficient for the analysis of the $\mathrm{Cu}$ content and therefore it had to be increased to allow multiple runs for the same samples. The limits of detection were satisfactory, although further improvement is feasible, either by preconcentrating larger amounts of sample solution using higher concentrations of both the surfactant and chelating agent or by diluting the surfactant-rich phase in a smaller volume of methanolic solution. The precision of this method was established by repeatedly $(\mathrm{n}=10)$ using $10.0 \mu \mathrm{g} \mathrm{L}^{-1}$ solutions of $\mathrm{Cu}$. The relative standard deviation was found to be 1.9 for $\mathrm{Cu}$.

\section{Interferences effects}

In view of the high selectivity provided by flame atomic absorption spectrometry, the only interferences studied were those related to the preconcentration step. The results shown in Table 2 show that the $\mathrm{Cu}$ recoveries are almost quantitative in the presence of the interfering cations.

\section{Preconcentration and determination of $\mathrm{Cu}$ in river and} sea water samples

To test the reliability of the proposed method for the assay of the $\mathrm{Cu}$ ion, it was applied to an analysis of sea and river water samples. Water samples were filtered using a $0.45 \mu \mathrm{m}$ pore size membrane filter to remove the
Table 1. Analytical characteristics of the method

\begin{tabular}{lc}
\hline Parameter & Analytical feature $(\mathrm{Cu})$ \\
\hline Preconcentration factor & 88 \\
$\mathrm{LOD}^{a}\left(\mu \mathrm{g} \mathrm{L}^{-1}\right)$ & 0.04 \\
R.S.D $(\%)$ & 1.9 \\
Regression equation & $3.9 \times 10^{-2} \mathrm{C}+0.020$ \\
Correlation coefficient $(\mathrm{R})$ & 0.9991 \\
Linear range $\left(\mu \mathrm{g} \mathrm{L}^{-1}\right)$ & $0.05-50.0$ \\
\hline${ }^{a}$ The limit of detection was calculated from $3 \mathrm{~S}_{\mathrm{b}} / \mathrm{m}$ equation, which $\mathrm{m}$ is \\
slope of calibration curve and $\mathrm{S}_{\mathrm{b}}$ is standard deviation of blank sample $\left(\mathrm{S}_{\mathrm{b}}\right.$ is \\
obtained from ten consecutive measurements of blank).
\end{tabular}

Table 2. Effect of foreign ions on the preconcentration and determination of the $\mathrm{Cu}$ content $\left(50 \mathrm{ng} \mathrm{mL}^{-1}\right)$

\begin{tabular}{lcr}
\hline Ions & $\begin{array}{c}\text { Concentration } \\
\left(\mathrm{mg} \mathrm{L}^{-1}\right)\end{array}$ & Recovery \% \\
\hline $\mathrm{Na}^{+}$ & $3 \times 10^{4}$ & 101.1 \\
$\mathrm{~K}^{+}$ & $3 \times 10^{4}$ & 99.3 \\
$\mathrm{Ca}^{2+}$ & 100 & 100.4 \\
$\mathrm{Mg}^{2+}$ & 50 & 100.1 \\
$\mathrm{Ag}^{+}$ & 2 & 98.9 \\
$\mathrm{Al}^{3+}$ & 2 & 101.1 \\
$\mathrm{Fe}^{3+}$ & 3 & 99.1 \\
$\mathrm{Co}^{2+}$ & 2 & 98.8 \\
$\mathrm{Ni}^{2+}$ & 10 & 100.7 \\
$\mathrm{Zn}^{2+}$ & 3 & 100.5 \\
$\mathrm{Cd}^{2+}$ & 5 & 99.5 \\
$\mathrm{Mn}^{2+}$ & 5 & 99.5 \\
$\mathrm{Hg}^{2+}$ & 2 & 99.8 \\
$\mathrm{Ba}^{2+}$ & 100 & 101.7 \\
$\mathrm{~Pb}^{2+}$ & 5 & 99.7 \\
$\mathrm{Cr}^{3+}$ & 2 & 100.5 \\
\hline
\end{tabular}

Table 3. Determination of $\mathrm{Cu}$ in sea and river water samples

\begin{tabular}{lcrc}
\hline Sample & Added $/ \mu \mathrm{g} \mathrm{L}^{-1}$ & Found $/ \mu \mathrm{g} \mathrm{L}^{-1}$ & Recovery \% \\
\hline Sea water & - & $4.5( \pm 0.1)$ & - \\
& 4 & $8.3( \pm 0.1)$ & 99.5 \\
River water & 10 & $14.6( \pm 0.2)$ & 101.8 \\
& - & $5.8( \pm 0.1)$ & - \\
& 10 & $9.9( \pm 0.1)$ & 100.9 \\
& $16.2( \pm 0.2)$ & 99.9 \\
\hline
\end{tabular}

Sample volume $60 \mathrm{~mL}$. ${ }^{\mathrm{a}}$ Mean of three determinations.

suspended particulate matter. As shown in Table 3, the proposed method was applied successfully to the preconcentration of trace amounts of $\mathrm{Cu}$ in sea and river water samples and spiked water samples.

\section{Conclusions}

We proposed the use of cloud-point extraction as an alternative method for the preconcentration of $\mathrm{Cu}$ before determination by FAAS. The surfactant-rich phase could be introduced into the nebulizer of a flame atomic 
absorption spectrometer after dilution with acidified methanol. The lowest level of $\mathrm{Cu}$ determination by this method is $0.04 \mu \mathrm{g} \mathrm{L}^{-1}$, and its relative standard deviation is 1.9. The method allows the determination of $\mathrm{Cu}$ at $\mathrm{ppb}$ levels in water samples by FAAS which is available in most laboratories. The proposed method is simple, sensitive, inexpensive and accurate. Furthermore, in comparison with solvent extraction methods it is much safer since only a small amount of the surfactant which has a low toxicity is used.

\section{References}

1. Sant'Ana, O. D.; Jesuíno, L. D.; Cassella, R. J.; Carvalho, M. B.; Santelli, R. E.; J. Braz. Chem. Soc. 2003, 14, 728.

2. Parmeggiani, L. Encyclopaedia of Occupational Health and Safety, $3^{\text {rd. }}$ ed., International Labor Organization: Geneva, 1983; Vol. 1.

3. Pramauro, E.; Prevot, A. B.; Pure Appl. Chem. 1995, 4, 551.

4. Manzoori, J. L.; Nezhad, G. K.; Anal. Chim. Acta 2004, 521, 173.

5. Forstner, U. Polution in the Aquatic Environment; Springer Verlag: Berlin, 1983.

6. Manzoori, J. L.; Bavili-Tabrizi, A.; Anal. Chim. Acta 2002, 470, 215.

7. Laespada, M.E.F.; Pavon, J.L.P.; Cordero, B.M.; Analyst 1993, 118, 209.

8. Shemirani, F.; Abkenar, S.D.; Mirroshandel, A.A.; SalavatiNiasari M.; Kozania R.R.; Anal. Sci. 2003, 19, 1453.

9. Shemirani, F.; Abkenar, S.D.; Kozania R.R..; Salavati-Niasari M.; Mirroshandel, A. A.; Can. J. Anal. Sci. Spectrosc. 2004, 49,31 .

10. Paleologos, G. D. L.; Tzouwara-Karaynni, S. M.; Karayanis, M. T.; Anal. Chim. Acta 2002, 458, 241.

11. Paleologos, E. K.; Stalikas, C. D.; Karayannis, M. I.; Analyst 2001, 126, 389.

12. Silva, M. F.; Fernandez, L.; Olsina, R. A.; Stacchiola, D.; Anal. Chim. Acta 1997, 342, 229.
13. Manzoori, J. L.; Bavili-Tabrizi, A.; Microchem. J. 2002, 72, 1.

14. Silva, M.A.M.; Frescura, V.L.A.; Aguilera, F.J.N.; Curtius, A.J.; J. Anal. At. Spectrom. 1998, 13, 1369.

15. Rosen, M. J.; Surfactants and Interfacial Phenomena; Wiley: New York, 1987

16. Corti, M.; Minero, C.; Degiorgio,; V. J. Phys. Chem. 1984, 88, 309.

17. Chen, J.; Teo, K. C.; Anal. Chim. Acta 2001, 450, 215.

18. Kulichenko, S. A.; Doroschuk, V. O.; Lelyushok, S. O.; Talanta 2003, 59, 767.

19. Stalikas, C.D.; Trends Anal. Chem. 2002, 21, 343.

20. Bezerra, M.D.; Arruda, M.A.Z.; Ferreira, S.L.C.; Appl. Spectrosc. Rev. 2005, 40, 269.

21. Silva, M.F.; Fernandez, L.; Olsina, R.; Stacchiola, D.;Anal. Chim. Acta. 1997, 42, 229.

22. Igarashi, S.; Endo, K.; Anal. Chim. Acta 1996, 320, 133.

23. Pinto, C. G.; Pavon, J.L. P.; Cordero, B. M.; Beato, E. R.; Sanchez, S. G.; J. Anal. At. Spectrom. 1996, 11, 37.

24. Chen, J.C.; Teo, K.C.; Anal. Chim. Acta. 2001, 450, 215.

25. Manzoori, J.L.; Tabrizi, A.B.; Anal. Chim. Acta 2002, 470, 215.

26. Chen, J.R.; Xiao, S.M..; Wu, X.H.; Fang, K.M.; Liu, W.H.; Talanta 2005, 67, 992.

27. Li, J.; Liang, P.; Shi, T.Q.; Lu, H.B.; Atom. Spectrosc. 2003, 24, 169.

28. Tang, A.N.; Jiang, D.Q.; Jiang, Y.; Wang, S.W.; Yan, X.P.; J. Chromatogr. A, 2004, 1036, 183.

29. Teo, K.C.; Chen, J.C.; Analyst 2001, 126, 534.

30. Doroschuk, V.O.; Lelyushok, S.O.; Ishchenko, V.B.; Kulichenko, S.A.; Talanta 2004, 64, 853.

31. Paleologos, E.K.; Giokas, D.L., Tzouwara-Karayanni, S.M.; Karayannis, M.I.; , Anal. Chim. Acta 2002, 458, 241.

32. Giokas, D.L.; Paleologos, E.K.; Karayannis, M.I.; Anal. Bioanal. Chem. 2002, 373, 237.

33. Ohashi, A.; Ito, H.; Kanai, C.; Imura, K. Ohashi; Talanta 2005, 65,525 .

34. Bezerra, M.A.; Conceicao, A. L. B.; Ferreira, S. L. C.; Microchim. Acta 2006, 154, 149.

Received: February 22, 2007

Web Release Date: November 7, 2007 